\title{
Circular economy: advancement of European Union countries
}

\author{
Ewa Mazur-Wierzbicka* (i)
}

\begin{abstract}
Background: Circular economy (CE) is a development priority of the European Union and it is part of the EU industrial strategy. The transition to a more circular economy is an essential contribution to the EU's efforts to develop a sustainable, low carbon, resource-efficient and competitive economy. The author focuses her CE-related reflections and research in this paper on the macro-level (research subjects: $28 \mathrm{EU}$ countries), the level which is least represented in scholarly publications addressing CE (as follows from the analysis of literature in the Scopus database). This study aims to fill this gap partially. The aim of this paper is to identify and group the EU-28 countries according to their advancement towards circular economy. CE indicators proposed by the European Commission were used for the analysis. Given the research subjects and after an analysis of the literature they were concluded to be the most adequate. The theoretical part was based on an analysis of the literature, whereas the empirical work used the principal components analysis, hierarchical and k-means clustering and a grade correspondence-cluster analysis.

Results: On the basis of the research, the existence of a "two-speed Europe" was identified in terms of EU countries' advancement towards CE. Leading countries, those most advanced in pursuing operation according to CE principles, include Germany, Belgium, Spain, France, Italy, the Netherlands and the United Kingdom. The second pole accommodates EU countries in which transformation towards CE is happening at the slowest pace. This group includes mainly countries of the Central and Eastern Europe and the countries of the south of Europe.

Conclusions: Differentiated levels of advancement of individual countries towards CE result inter alia from the adoption by some of the latter of different development strategies for their economies' transitioning to circular economy (according to recommendations of EU ministers at the Environment Council in June 2016) and also from the differences occurring in social and economic development (it is mostly noticeable between the EU-15 and the EU-13 countries). Unfortunately, as can be concluded from the effects obtained so far, only a few of the adopted development strategies may be considered effective in meeting the challenges of circular economy according to the European Union's standards.
\end{abstract}

Keywords: Circular economy, EU countries, Indicators

\section{Introduction}

An increased interest of scholars, entrepreneurs and decision-makers in the issues of circular economy $(\mathrm{CE})$ has been observed over the last few years.

The ideas of circular economy were developed at the start mainly on the scholarly ground-ecological

*Correspondence: ewa.mazur-wierzbicka@usz.edu.pl

Institute of Management, University of Szczecin, 70-453 Szczecin, Poland economics (e.g. [9, 18, 49]), environmental economics (e.g. Pearce and Turner [82]), functional service economy (performance economy) (e.g. Stahel [91]) or on the ground of industrial ecology (e.g. [54, 67, 88]). They have inspired the interest of decision-makers [16], [30] and of the business sector [20,25] relatively recently (early twenty-first century).

The term "CE" is difficult to define. It results i.a. from the development of this concept in various areas, i.e. science, business or politics on various micro, meso and
Springer Open

(c) The Author(s) 2021. Open Access This article is licensed under a Creative Commons Attribution 4.0 International License, which permits use, sharing, adaptation, distribution and reproduction in any medium or format, as long as you give appropriate credit to the original author(s) and the source, provide a link to the Creative Commons licence, and indicate if changes were made. The images or other third party material in this article are included in the article's Creative Commons licence, unless indicated otherwise in a credit line to the material. If material is not included in the article's Creative Commons licence and your intended use is not permitted by statutory regulation or exceeds the permitted use, you will need to obtain permission directly from the copyright holder. To view a copy of this licence, visit http://creativecommons.org/licenses/by/4.0/. 
macro-planes. A number of definitions and interpretations of this concept have been established over the years (often very different, sometimes inconsistent). Their analysis shows that $\mathrm{CE}$ is considered in the categories of: a strategy $[5,55,90]$, a new economic paradigm $[45,47]$, an industrial model [103], an industrial system [25, 56, 79], an economy system [68], an economic system [78] or a new "business and development model" [50].

It may be assumed that CE-related activity should result in a more sustainable and competitive operation of economic systems at the micro [8, 10, 23, 62, 64, 83], meso [3, 6, 22, 57, [60], 105], and macro [48, 63], Hacking and Xie 2019, $[41,53,61,71,76]$ level, thus bringing economic, social and environmental benefits $[12,13,14$, $43,51,72,89]$. In assumption, implementation of circular economy is supposed to lead ultimately to building a system in which the implementation of sustainable development goals is coordinated in three dimensions: economy, society and natural environment [102].

Active steps in the framework of CE have been taken in the European Union since 2014, though relevant aspects appeared in EU regulations as early as in the 1970s. The following may be cited as examples: regulations concerning waste [36, 92, 93, 95], the assessment of the impact of some public and private undertakings on the environment [94], recycling of end-of-life vehicles [37], used electrical and electronic equipment [39], the adopted Sixth Environment Action Programme [38], Thematic Strategy on the Sustainable Use of Natural Resources [15], or Roadmap to a Resource Efficient Europe [30].

At the moment $\mathrm{CE}$ has become a priority of the European Union's economic policy. Closing the loop-an EU Action Plan for the Circular Economy [17] is considered the fundamental document here as it includes proposals for actions to be carried out in the EU in the coming years. They are intended to contribute to a change in the model of economic development, i.e. from a linear economy model to a circular economy model. The document also includes legal requirements which oblige member states to implement actions initiated at the EU level for selected areas, i.e. eco-innovation, eco-labelling, nontoxic environment, chemicals and also critical raw materials and fertilisers.

$\mathrm{CE}$ is defined there as "an economy, where the value of products, materials and resources is maintained (...) for as long as possible, and the generation of waste minimized" [17].

The EU has adopted a number of significant documents concerning CE recently, that is: Regulation (EU) 2018/848, Directive (EU) 2018/849, Directive (EU) 2018/850, Directive (EU) 2018/851 or Directive (EU) 2018/852. The EC has published the monitoring framework for the Circular Economy [31] and it has also adopted a document "A New Circular Economy Action Plan. For a Cleaner and More Competitive Europe" [37].

From the perspective of $\mathrm{CE}$ development and of the transformation of economies towards $\mathrm{CE}$, monitoring the implementation of its goals, undertaken actions, at all levels, i.e. micro, meso as well as macro, is fundamental [28]. The monitoring process is a difficult task, mainly as there is no single generally acceptable set of indicators or one such indicator [35], or as there is a great variety of indicators-which may result from a different understanding of the CE concept by individual stakeholders.

A lot of international organizations which currently deal with the issues of circular economy have brought forward their solutions for monitoring progress in implementing circular economy, for example the OECD [80], the World Bank [101], the WBCSD [99], the EEA [35], the Ellen MacArthur Foundation [24-27] and the EASAC [28].

Some EU countries have created their "their own systems of indicators", which in consequence makes it difficult to compare effects of CE-related activity between individual countries. These are, for example: the Netherlands [21, 86, 87], France [69], The French Ministry of Ecological and Solidarity Transition [97], Italy [52, 74], Portugal [75].

Measuring or monitoring $\mathrm{CE}$ has also been carried out by researchers, who built indicators for this purpose on the basis of their own reviews of the literature and analyses $[46,53,58,65,71,76,77,81,100]$

The question of the selection of indicators to CE assessment is a subject of discussions. They mainly focus on the measurement of the advancement of transformation towards CE [87] or of the efficiency of implementation of $\mathrm{CE}$ goals, on the identification of a difference between $\mathrm{CE}$ assessment indicators and linear economy assessment indicators [28], on establishing the reference point for which progress in implementing $\mathrm{CE}$ may be traced [55] or on the efficiency (national, regional or local) of measuring CE implementation [100].

By concluding that "In order to assess progress towards a more circular economy and the effectiveness of action at EU and national level, it is important to have a set of reliable indicators" [17], the European Commission undertook works on creating a CE monitoring framework, which was adopted in 2018. It is the EC's proposal on measuring progress in implementing $\mathrm{CE}$ in the $\mathrm{EU}$ and in member states. It consists of a set of indicators, taking into account the main elements of $\mathrm{CE}$ which are intended to measure the progress of actions aimed at a transformation towards $\mathrm{CE}$ at all stages of the life cycle of raw materials, goods and services and also at the innovation and competitiveness aspects. 
These indicators are grouped into four areas of CE policy strictly relating to: production and consumption, waste management, secondary raw materials, competitiveness and innovation [34] and priority areas included in the EU action plan for the Circular Economy [17].

Most of the indicators included in the EU monitoring framework focus on waste, which, according to the European Economic and Social Committee, results to a great degree from the fact that "data on waste is strong, consistent and comparable. However, any future monitoring needs to move beyond waste and recycling (...)" [34].

Pursuant to the EU's action plan for sustainable economy (Circular Economy Action Plan), the so-called European Green Deal, and the Annual Sustainable Growth Strategy 2020 [32], the Commission will update the framework for monitoring circular economy and will also reinforce the monitoring of national plans and measures that aim to accelerate their transition to circular economy.

The planned new CE indicators are intended to take into account the existing target areas and also the relationships between circularity, climatic neutrality and the goal of achieving zero emissions. It is assumed that indicators relating to the use of resources, including the consumption and material footprint, will also be developed. It is additionally assumed that the projects implemented under the "Horizon Europe" and the Copernicus data will contribute to improving circularity metrics (which are not yet reflected in official statistical data) at various levels [33].

In the works on CE indicators, it is also worth addressing the aspects which should be reflected mainly in the production and consumption area identified in the monitoring framework, which is pointed to by the European Economic and Social Committee [34]. This concerns in particular issues to which the EU pays particular attention, while it does not translate into CE indicators [17]. Such a situation takes places even in the case of designing products (Europroject) or specifying a consumer's place in resource flows: "(...) any future monitoring needs to (...) focus on design, production and consumption" [34].

The relevant literature features numerous CE-focused studies, though a certain shortage may be noticed, especially when it comes to analyses on the macro-level, including comparative investigations.

Having the above in mind, this paper undertakes reflections in terms of $\mathrm{CE}$ at the macro-level, where 28 European Union member states (EU-28) are the research subjects, to fill the identified gap. The article focuses mainly on grouping the EU-28 countries according to their advancement towards circular economy. The aim of the paper is to assess the level of progress towards circular economy of member states of the European Union in 2010-2018.

The following research tasks corresponding to the main goal are also presented in the study:

1. Grouping the analysed $\mathrm{CE}$ scales by means of the principal components analysis (PCA).

2. Grouping the EU-28 countries by means of hierarchical and k-means clustering.

3. Indication at the same time similar countries and similar scales by means of a grade correspondencecluster analysis.

On the basis of a literature review and scoping review (initial assessment of the body and scope of available literature; it allows, i.a., to determine the type and scope of research conducted) [7], the author decided to use CE indicators proposed by the European Commission in its monitoring framework. To date, the said EU document is the only CE monitoring framework in the world developed at the pan-national level. Understandably, it focuses on the macro-dimension, which is also the subject of this analysis. The time horizon for the analysis covered the years 2010-2018.

This paper has the following structure. The introduction, which focuses on the presentation of relevant issues on the CE essence, possibilities to monitor it and the article's aims, is followed by a section with information about the methodology applied. Section three presents results of the author's analyses, while section four contains a discussion. The last section brings a summary of the article, which also includes limitations of the analyses presented in this paper and names possible directions of further research.

\section{Methods}

On the basis of an analysis of the literature, the author decided to use the CE monitoring indicators proposed by the European Commission. To date they are the only framework for monitoring $\mathrm{CE}$ throughout the world developed at the pan-national level. Therefore, they focus on the macro-level which is also the subject of this analysis. The Eurostat database was the source of the data.

The spatial scope of the research covered $28 \mathrm{EU}$ member states (EU-28). The time horizon for the analysis covered 2010-2018. The analyses began in 2010 due to the availability of statistical data and also due to the beginning of applicability of an important EU strategy-the Europe 2020 strategy (2010), in which aspects relating to CE were already included.

Conducting the research process was possible thanks to the use of an array of analyses. Statistical analyses 
were computed by means of PQStat package, version 1.8.0.338 and GradeStat, version 2.5.

Selection of relevant diagnostic variables which would fully characterize the discussed issue carries great importance in the research. The assessment of diagnostic variables in these terms was conducted taking into account the following principles: universality, measurability, availability of quantitative data, data quality, interpretability, variables impact, content validity, transparency and possibility of aggregation [66, 104].

The first stage in the research process was to identify all indicators employed by the EC in its monitoring framework. Then, the features of the least diagnostic value were eliminated from the original set of features, finally classifying 13 circular economy indicators.

The research takes into account partial indicators which include information for all EU member states, indicators for which the data were aggregated (self-sufficient for raw material; contribution of recycled material to raw materials demand) and those not entirely developed or included in statistics (Green Public Procurement, Food waste).

The second stage involved preparation of the data for the analysis. In the first phase it consisted in averaging the data for 2010-2018 for each country and for the 13 indicators to create 13 scales. In the second phase of the process, the said scales were standardized for $\mathrm{min} / \mathrm{max}$ in order to obtain a set of results on the same scale which would be suitable for multidimensional analyses. Names of scales were changed to symbols for practical reasons, whereby:

- Generation of municipal waste per capita (cei_ pc031).

- Generation of waste excluding major mineral wastes per GDP unit (cei_pc032).

- Generation of waste excluding major mineral wastes per domestic material consumption (cei_pc033).

- Recycling rate of municipal waste (cei_wm011).

- Recycling rate of all waste excluding major mineral waste (cei_wm010).

- Recycling rate of packaging waste by type of packaging (cei_wm020).

- Recycling rate of e-waste (cei_wm050).

- Recycling of biowaste (cei_wm030).

- Recovery rate of construction and demolition waste (cei_wm040).

- Circular material use rate (cei_srm030).

- Trade in recyclable raw materials (cei_srm020).

- Private investments, jobs and gross value added related to circular economy sectors (cei_cie010).

- Patents related to recycling and secondary raw materials (cei_cie020).
Statistical analyses were conducted in the third stage of the research process. It opened with an analysis of principal components, by means of which the analysed scales were grouped. Bartlett's test, $x^{2}-229.90, \mathrm{df}=78$, $p<0.0001$, was used to verify the hypothesis that correlation coefficients between the variables are zero (that is, the correlation matrix is the identity matrix). The KeiserMayer-Olkin test $-\mathrm{KMO}=0.5560$ was also employed, which was used to verify the degree of correlation between primary variables, that is the strength of evidence for the validity of analysing principle components. In the next stage, hierarchical clustering (by means of the agglomerative procedure) and $k$-means clustering were conducted by grouping the examined EU member states. The last analysis to conduct was the grade correspondence-cluster analysis, which allowed a demonstration of similar countries and similar scales at the same time. The probability value was assumed significant at $p<0.05$, and a highly significant probability value was assumed at $p<0.01$.

\section{Results}

\section{Principal component analysis}

The probability value for the Bartlett's test indicates the truth of the hypothesis which claims a significant difference between the correlation matrix obtained and the identity matrix, that is a significant variable correlation. The estimated KMO coefficient is at an average level at 0.5560 . Therefore, the premises for conducting the principal components analysis can be deemed as sufficient.

The eigenvalues obtained from Table 1 demonstrate that four principal components are sufficient to describe the data well and at the same time to simplify their 13-dimension structure. The eigenvalue for the

Table 1 Eigenvalues_-principal components analysis

\begin{tabular}{lllll}
\hline $\begin{array}{l}\text { Component } \\
\text { number }\end{array}$ & Eigenvalue & Variance $\%$ & $\begin{array}{l}\text { Cumulative } \\
\text { sum }\end{array}$ & Cumulative \% \\
\hline 1 & 4.9402 & 38.0013 & 4.9402 & 38.0013 \\
2 & 2.0426 & 15.7124 & 6.9828 & 53.7137 \\
3 & 1.6699 & 12.8455 & 8.6527 & 66.5592 \\
4 & 1.1811 & 9.0852 & 9.8338 & 75.6444 \\
5 & 0.9488 & 7.2988 & 10.7826 & 82.9433 \\
6 & 0.7945 & 6.1116 & 11.5771 & 89.0548 \\
7 & 0.4416 & 3.3972 & 12.0188 & 92.4521 \\
8 & 0.3282 & 2.5243 & 12.3469 & 94.9764 \\
9 & 0.2431 & 1.8700 & 12.5900 & 96.8464 \\
10 & 0.1805 & 1.3883 & 12.7705 & 98.2347 \\
11 & 0.1253 & 0.9638 & 12.8958 & 99.1986 \\
12 & 0.0740 & 0.5689 & 12.9698 & 99.7675 \\
13 & 0.0302 & 0.2325 & 13.0000 & 100.0000 \\
\hline
\end{tabular}


first component is 4.9402 and the percentage of variance explained by it is 38.0013 . The second component explains significantly fewer variances, i.e. $15.7124 \%$ and its eigenvalue is 2.04. According to the Keiser criterion, it is the first four components that will be sufficient in interpretation since their eigenvalue is greater than 1 . Taking into account the first 4 principal components allows an explanation of $75.6444 \%$ of the variation observed.

Factor loadings are included in Table 2.

According to the data included in Table 3:

Component 1 is best explained by:

1. cei_wm011,

2. cei_wm010,

3. cei_wm030,

4. cei_srm030.

Component 2 is best explained by:

1. cei_pc031,

2. cei_pc032,

3. cei_pc033.

Component 3 is best explained by:

1. cei_wm020,

2. cei_cie010,

3. cei_cie020.

Component 4 is best explained by:

1. cei_wm050,

2. cei_wm040,

3. cei_srm020.

Table 2 Factor loadings - principal components analysis

\begin{tabular}{lcccc}
\hline Number & Component & Component & Component & \multicolumn{1}{l}{ Component } \\
& $\mathbf{1}$ & $\mathbf{2}$ & $\mathbf{3}$ & $\mathbf{4}$ \\
\hline cei_pc031 & -0.4493 & -0.4670 & -0.1856 & 0.0030 \\
cei_pc032 & 0.3459 & 0.8625 & -0.0697 & 0.0476 \\
cei_pc033 & -0.3245 & 0.8371 & -0.0411 & -0.2100 \\
cei_wm011 & -0.9053 & 0.0333 & -0.2846 & 0.0901 \\
cei_wm010 & -0.7140 & -0.2667 & -0.2442 & -0.3286 \\
cei_wm020 & -0.6770 & 0.0652 & -0.4580 & 0.2939 \\
cei_wm050 & 0.0189 & 0.3047 & -0.5741 & 0.6004 \\
cei_wm030 & -0.8413 & -0.1411 & -0.3101 & -0.0768 \\
cei_wm040 & -0.3993 & 0.1913 & 0.0221 & -0.4437 \\
cei_srm030 & -0.7512 & 0.3781 & 0.0353 & -0.3380 \\
cei_srm020 & -0.6495 & 0.0405 & 0.3855 & 0.3849 \\
cei_cie010 & -0.6918 & 0.0783 & 0.5661 & 0.1767 \\
cei_cie020 & -0.6272 & 0.0578 & 0.6179 & 0.2744 \\
\hline
\end{tabular}

Table 3 Contribution of variables-principal components analysis

\begin{tabular}{lclll}
\hline Number & Component & Component & Component & Component \\
& $\mathbf{1}$ & $\mathbf{2}$ & $\mathbf{3}$ & $\mathbf{4}$ \\
\hline cei_pc031 & 4.0860 & 10.6789 & 2.0627 & 0.0008 \\
cei_pc032 & 2.4214 & 36.4177 & 0.2907 & 0.1915 \\
cei_pc033 & 2.1316 & 34.3053 & 0.1011 & 3.7341 \\
cei_wm011 & 16.5917 & 0.0541 & 4.8520 & 0.6878 \\
cei_wm010 & 10.318 & 3.4830 & 3.5706 & 9.1430 \\
cei_wm020 & 9.2783 & 0.2084 & 12.5636 & 7.3153 \\
cei_wm050 & 0.0072 & 4.5450 & 19.7399 & 30.5244 \\
cei_wm030 & 14.3283 & 0.9743 & 5.7603 & 0.4992 \\
cei_wm040 & 3.2276 & 1.7915 & 0.0294 & 16.6692 \\
cei_srm030 & 11.4224 & 6.9980 & 0.0744 & 9.6745 \\
cei_srm020 & 8.5380 & 0.0802 & 8.8997 & 12.5408 \\
cei_cie010 & 9.6863 & 0.3004 & 19.1889 & 2.6428 \\
cei_cie020 & 7.9632 & 0.1634 & 22.8666 & 6.3765 \\
\hline
\end{tabular}

The location of the EU countries on the coordinate system on the basis of components 1 and 2 is presented in Fig. 1.

The next stage of the research process involved hierarchical and $\mathrm{k}$-means clustering in order to group the EU member states.

The hierarchical cluster analysis shows that there are two groups of countries. The first group includes: Belgium, the Netherlands, Denmark, Luxembourg, Austria, Germany, Spain, France, Italy and the UK. The other countries form the second group cluster Fig. 2.

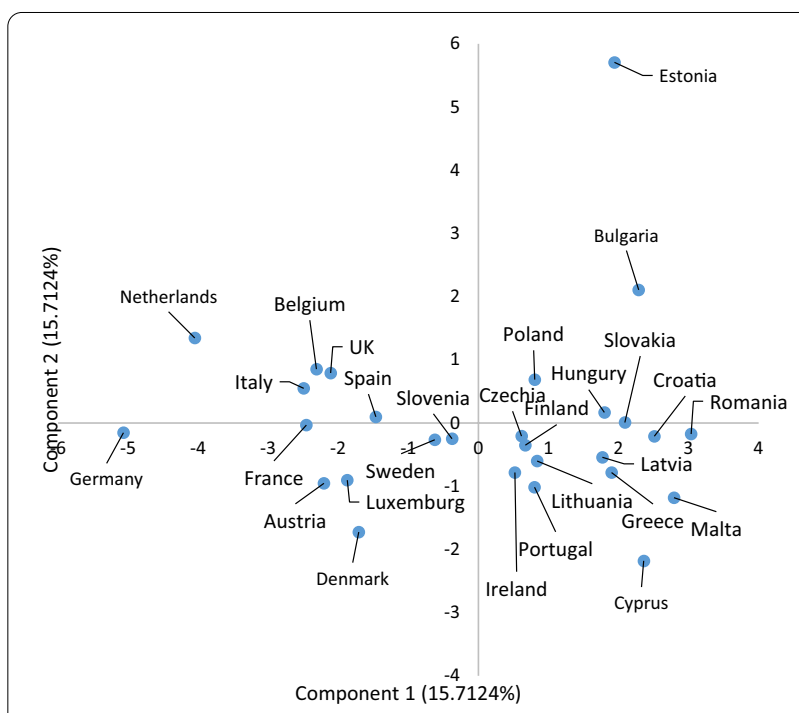

Fig. 1 Location of the EU countries in the coordinate system on the basis of components 1 and 2 


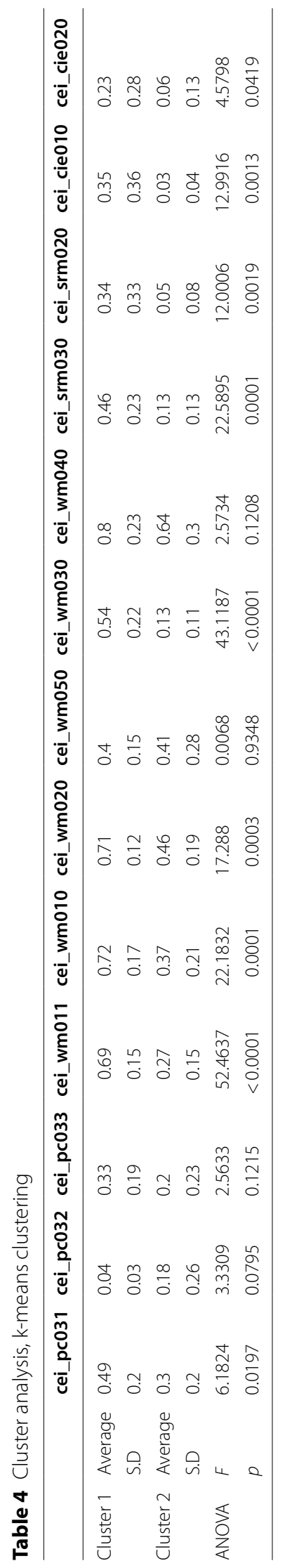




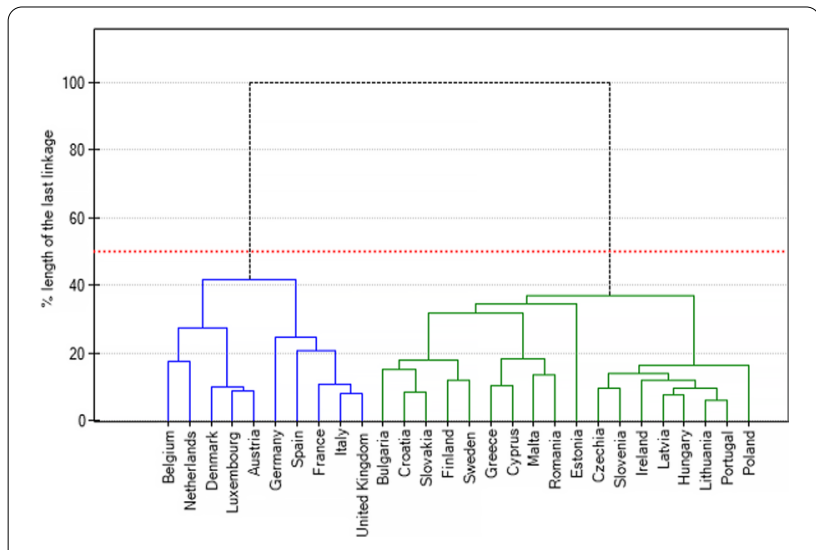

Fig. 2 Hierarchical cluster analysis. Linkage method-Ward's method. Euclidean distance of all elements

As seen in the data obtained when applying a cluster analysis by means of $\mathrm{k}$-means clustering, the EU-28 countries were divided into two clusters (Table 4).

The first cluster is made up of the following countries: Belgium, Denmark, Germany, Spain, France, Italy, Luxembourg, the Netherlands, Austria and the United Kingdom.

The following were placed in the second cluster: Bulgaria, Czechia, Estonia, Ireland, Greece, Croatia, Cyprus, Latvia, Lithuania, Hungary, Malta, Poland, Portugal, Romania, Slovenia, Slovakia, Finland and Sweden.

Both of these clusters differ significantly $(p<0.01)$ in terms of the generation of municipal waste per capita scale, where the results are higher for the first cluster.

Results of scales: generation of waste excluding major mineral wastes per GDP unit and generation of waste excluding major mineral wastes per domestic material consumption are not significantly different $(p>0.05)$ between clusters.

Results of scales: recycling rate of municipal waste, recycling rate of all waste excluding major mineral waste and recycling rate of packaging waste by type of packaging are significantly different $(p<0.01)$ between clusters, where the results are higher for the first cluster.

In the case of the recycling rate of e-waste scale, there is no significant difference $(p>0.05)$ between clusters.

Results of the recycling of biowaste scale are significantly different $(p<0.01)$ between clusters, where the results are higher for the first cluster.

In the case of the recovery rate of construction and demolition waste scale, there is no significant difference $(p>0.05)$ between clusters.

Results of scales: circular material use rate, trade in recyclable raw materials and private investments, jobs and gross value added related to circular economy sectors are significantly different $(p<0.01)$ between clusters, where the results are higher for the first cluster.

For the patents related to recycling and secondary raw materials scale, the difference between clusters is significant $(p<0.05)$.

The last stage of the research process involved conducting the grade correspondence-cluster analysis allowing a demonstration of similar countries and similar scales at the same time.

The map in Fig. 3 presents three pieces of information, that is:

1. Column width shows what share in the matrix is taken by values of a given variable.

2. Row height shows what share in the matrix is taken by values of a given country.

3. Colour intensity shows the overrepresentation coefficient-the more this coefficient is greater than 1, the more overrepresented the real result is in relation to the theoretical value expected for an even distribution. The more this coefficient is lower than 1 , the more underrepresented the real result is in relation to the theoretical value expected for an equal distribution.

The overrepresentation map in Fig. 3 shows that countries such as Germany, France, Spain, the United Kingdom and Italy are a group of similar entities with strong overrepresentation for scales: cei_cie010, cei_cie020 and cei_srm020. A completely opposite group of countries is formed by Bulgaria, Croatia, Estonia or Romania. However, a visual analysis of this map does not allow a clear

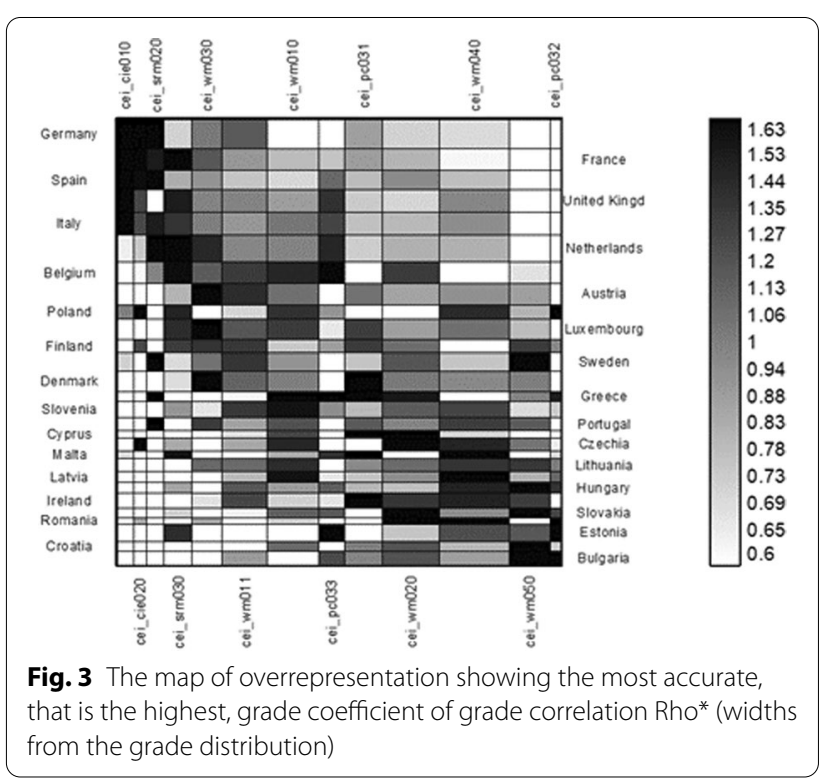


classification of the countries into clusters, which is why a cluster analysis was conducted.

As seen in the data included in Fig. 4, there are three clusters in the context of the analysed CE indicators.

The first cluster is made up of: Germany, France, Spain, the United Kingdom, Italy, the Netherlands and Belgium with relatively high overrepresentation of scales:

1. private investments, jobs and gross value added related to circular economy sectors,

2. patents related to recycling and secondary raw materials,

3. trade in recyclable raw materials,

4. circular material use rate,

5. recycling of biowaste.

This means that these countries lead in the above-mentioned actions. At the same time, their scales are highly underrepresented there:

1. recovery rate of construction and demolition waste,

2. recycling rate of e-waste,

3. generation of waste excluding major mineral wastes per GDP unit.

The third cluster made up of Cyprus, Czechia, Malta, Lithuania, Latvia, Hungary, Ireland, Slovakia, Romania, Estonia, Croatia and Bulgaria is the opposite of the first cluster, that is it demonstrates relatively high overrepresentation of scales: recovery rate of construction and demolition waste, recycling rate of e-waste and generation of waste excluding major mineral wastes per GDP unit and high underrepresentation of scales: private investments, jobs and gross value added related to circular economy sectors, patents related to recycling and secondary raw materials, trade in recyclable raw materials, circular material use rate and recycling of biowaste.

The second cluster accommodates countries with average results and includes Austria, Poland, Luxembourg, Finland, Sweden, Denmark, Greece, Slovenia and Portugal.

The columns extremely far apart include scales which are not correlated or that are even negatively correlated, e.g. the higher the private investments, jobs and gross value added related to circular economy sectors scores, the lower the generation of waste excluding major mineral wastes per GDP unit scores.

Table 5 shows all estimated correlation coefficients of the Spearman's rank between the analysed indicators. Generation of waste excluding major mineral wastes per GDP unit is negatively correlated with the majority of the other indicators save for generation of waste excluding

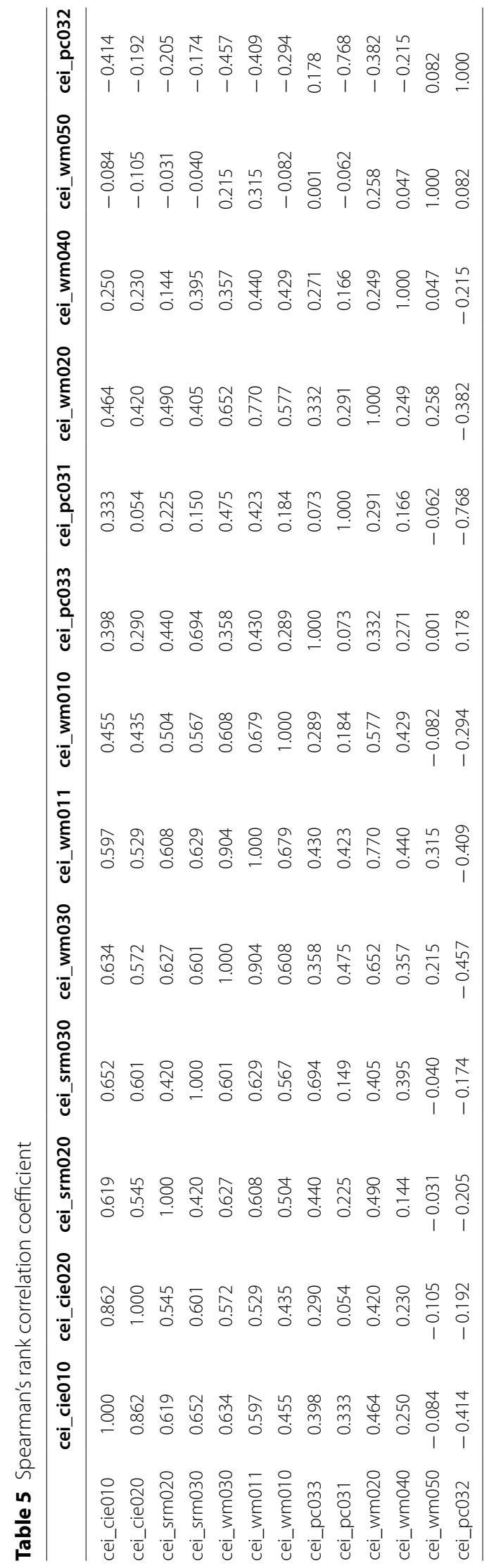




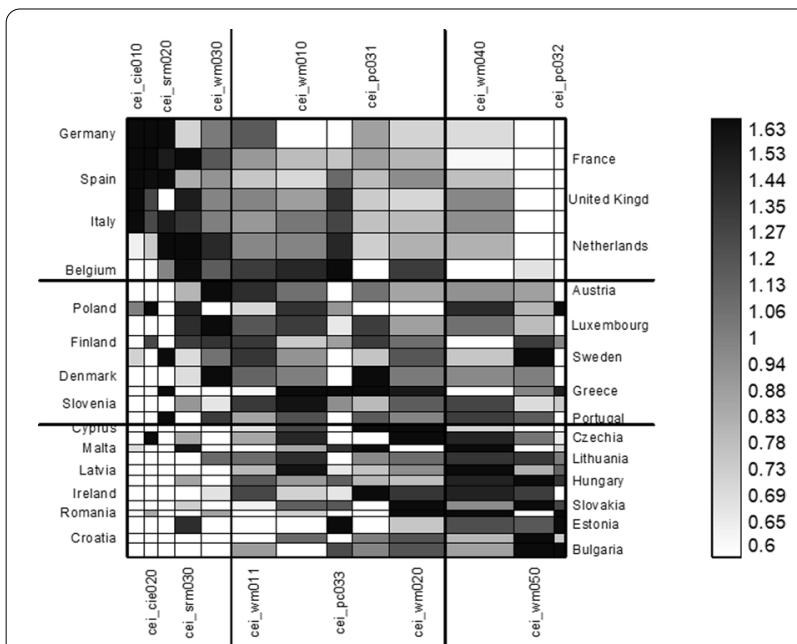

Fig. 4 Map of overrepresentation with a division in accordance with the cluster analysis

major mineral wastes per domestic material consumption and recycling rate of e-waste.

The inference conducted on the basis of the statistical analyses concerning transformation of EU countries towards circular economy led to the emergence of the "two-speed-Europe".

Leading countries, those most advanced in pursuing operation according to CE principles, include Germany, Belgium, Spain, France, Italy, the Netherlands and the United Kingdom. These are the countries of the so-called Old Union (i.e. those which have been joined by other European countries after 2004), economically highly developed countries.

The second pole accommodates EU countries in which transformation towards CE is happening at the slowest pace. This group is made up of: Cyprus, Czechia, Malta, Lithuania, Latvia, Hungary, Ireland, Slovakia, Romania, Estonia, Croatia and Bulgaria. Therefore, with the exception of Ireland these are mainly countries of the Central and Eastern Europe (after the political transformation) and the countries of the south of Europe.

\section{Discussion}

It may be assumed that the countries that are most advanced in their transformation towards the CE (highly industrialized countries) began to feel i.a. problems of excessive waste generation, exhaustion of resources, environmental pollution, increasing consumerism or unbalanced consumption much earlier than the economies of European countries which are developing more slowly (e.g. countries which belonged to the Eastern Bloc and only since the end of the 1980 s or the 1990s have their economies been operating according to the principles of free market and competitive economy).
The above problems reached the countries of the Central and Eastern Europe with a certain delay, therefore their activities aimed at implementing CE may be slightly slower in time, though they do occur.

These countries' lesser involvement in CE implementation may also be down, e.g. to the lack of a sufficiently developed infrastructure to process waste or to societies' lower CE-related awareness.

Another essential matter is the issue of financing activities which serve the implementation and functioning of economies of the Union's countries according to CE principles. Certainly, the countries' switching to circular economy is beneficial for the natural environment and in consequence for the people, but it does require greater $\mathrm{CE}$ awareness from the regulator, governing authorities, consumers and society in general in terms of implementation of advanced technologies and this, in turn, requires time and financial outlays.

The European Commission promotes CE-related activities emphasizing that the implementation of CE systems will have a positive impact on resource efficiency and will bring crucial economic benefits to EU countries.

The differentiated levels of advancement of individual EU countries towards CE also result from the adoption by some of them of different development strategies concerning their economies' transitioning to circular economy (according to recommendations of EU ministers at the Environment Council in June 2016) and also from their different approach to implementing CE. Some of them, in particular those belonging to the group of countries more advanced in their transformation towards CE, had undertaken activities compliant with the CE concept even before it was recognized by the European Commission as one of the most essential ones.

Thus, in Germany, as early as in 2002 separation of the economic growth from the use of materials was adopted as one of its economic goals, whereas in 2012 it adopted a statute which promotes circular economy and circular material use. In 2016 a document German Resource Efficiency Programme II: Programme for the sustainable use and conservation of natural resources [4] was published, whereas in 2019 a new law on packaging (Packaging Act) [84] entered into force. A lot of national initiatives or programmes that encourage CE are taken up in Germany, e.g. the German national resource efficiency programme ProgRess [4] or Program VDI [96].

The Netherlands is considered to be one of the European pioneers of CE-related initiatives, where activities relating to the CE concept were introduced in 2011 and in 2013 a report entitled "Opportunities for a circular economy in the Netherlands" was drawn up [2]. It identified opportunities for generating economic growth and increasing employment thanks to innovation in 
circular economy. In 2016, the Netherlands adopted a national programme Circular Economy in the Netherlands by 2050. It focuses on the main categories of the Dutch economy, i.e. biomass and food, construction, plastics, manufacturing and consumer goods. Reduced use of natural resources and making the import of natural resources independent, and thus increased supply security of raw materials, are the most desired effects of transformation towards CE in the Netherlands.

In turn in the United Kingdom the initiative called the Waste and Resources Action Plan (WRAP) has been developing since 2000. However, no circular economy strategy common to all regions has been drawn up. Nevertheless, CE is included in the industrial strategy "Building a Britain fit for the future". CE-related actions are supported by the 25-year Environmental Plan and the forthcoming Resource and Waste Strategy. Neither England nor Wales has drafted a regional CE strategy, whereas there is one in Scotland where in 2016 the government adopted a strategy to pursue circular economy. The two key elements of the strategy are: to develop a more comprehensive approach to producer responsibility by setting up a single framework for all product types which concern reuse, repair and remanufacture, while more fully exposing and addressing the costs of recycling and disposal; and to reduce all food waste by $33 \%$ by 2025 [70].

France is another country advanced towards CE, where an action plan for moving to a circular economy was developed in 2013 and the French Circular Economy Institute was established. In 2018 France adopted its Roadmap for Circular economy-50 measures for a $100 \%$ circular economy [97]. The strategy for a circular economy in France presumes, i.a., a reduction of natural resource use related to French consumption: a 30\% reduction in relation to GDP between 2010 and 2030, a $50 \%$ reduction in the amount of non-hazardous waste landfilled by 2025 compared to $2010,100 \%$ of plastics recycled, and a reduction of greenhouse gas emissions (by 8 million tonnes of $\mathrm{CO} 2$ each year thanks to plastic recycling). France participated in the circular economy North Sea Roundabout project [59]. At the moment it is the first EU country which transposed European directives on circular economy onto national law [44].

Moving on, Italy introduced its strategy "Towards a Model of Circular Economy for Italy-Overview and Strategic Framework" in 2017 [74]. Its aim is to direct the public opinion towards the concept of circular economy. It is the so-called integrated strategy-it focuses mainly on horizontal tools and policies. As seen in the report entitled Circular Economy Network, ENEA, Rapporto sull'Economia Circolare in Italia 2019, the Italian economy has one of the highest CE-monitoring indicators in the EU. This concerns the following five parameters: production, consumption, waste management, secondary raw materials and competitiveness and innovation.

At the beginning of June 2020 the Spanish Government published España Circular 2030, the new Strategy for Circular Economy in Spain until 2030 (2020). It contains circular economy objectives and a series of strategic orientations for the period 2020-2030. The strategy: sets up a series of objectives for 2020-2030 which will, inter alia, allow a $30 \%$ reduction in the national consumption of resources and a 15\% reduction in waste generation (as compared to 2010); contributes to Spain's efforts to transition to a sustainable, decarbonized, resource-efficient and competitive economy; and takes the form of successive 3-year action plans providing for concrete measures to deliver on circular economy. A number of CE-related initiatives at the national, regional, level are undertaken in Spain ("Seville Declaration" [19], "Extremadura 2030"-strategy for CE of the region of Extremadura [40]).

Belgium adopted a national CE strategy entitled Towards a Belgium as pioneer in the Circular Economy in 2014. The Roadmap contains 21 measures that aim to increase the potential of the circular economy by sharing and repairing products and sustainable waste management [42]. It has significant results especially in the area of recycling.

As seen in the above analysis, out of the EU countries most advanced in their transformation towards CE, only the United Kingdom does not have a national CE strategy. Such strategies have been created in other countries. Apart from this, CE strategies have been drawn up in these countries at the regional and local level. They relate to bottom-up initiatives taken by local self-government structures (often-cities). Of course, national CErelated strategies are also created in the EU countries in which transition to $\mathrm{CE}$ is proceeding at the slowest pace. Among the countries least advanced towards CE the following have relevant strategies: Malta (Sustainable Development Vision for 2050), Ireland (Towards a Resource Efficient Ireland: A National Strategy to 2020), or Slovakia (Slovak Republic towards green economy). It needs to be emphasized that officially these countries have committed to transform their economies in accordance with the CE idea, yet despite the undertaken legislative activity and other initiatives taken in this scope they are only at the initial phase of implementation. Special focus in these countries must be given to their further legislative activity, new social initiatives and new technological solutions in the field of, e.g. eco-innovation in order to accelerate their transformation towards CE.

On the basis of an assessment of the review of analyses and reports and documents presented in the literature, 
one may assume that the disproportion between individual countries in terms of their transformation towards $\mathrm{CE}$ will continue for the next few years.

As part of $\mathrm{CE}$ implementation, the European Union now attributes special importance to waste management. This is reflected, for example, in the indicators accommodated within the CE monitoring framework [31], among which those concerning waste constitute a significant group. When analysing the indicators adopted by the $\mathrm{EU}$, it is clear that recycling is among the few major CE elements [55]. On the basis of only those indicators that pertain to recycling, one can also identify groups of EU countries with a different level of advancement in applying it.

A similar case is with waste management in the European Union, where groups of countries moving at different speeds may also be named. When it comes to municipal waste, we may even identify a "multi-speed" $\mathrm{EU}$, under which three groups of countries are indicated, that is Recovery, Transition and Landfilling Countries [85]. It certainly translates into progress of individual counties falling under specific groups in the context of their advancement towards CE. It must be emphasized that the EU's long-term goal is to transform Europe into the so-called recycling society [17], that is one that avoids waste production, and if it occurs, it uses it as a resource. Appropriate waste management is a fundamental element ensuring resource efficiency and sustainable economic development of European countries, which is all in line with CE principles.

Actions to best support individual countries in their transformation towards $\mathrm{CE}$ are being now taken in the European Union. These actions involve, inter alia, creating incentives to invest in the area of $\mathrm{CE}$ by ensuring financial support under structural and investment funds, creating relevant market mechanisms and eliminating market flaws. One may hope that due to the emerging (as well as planned and prepared) documents of the European Commission concerning CE and CE-related documents or strategies developed by individual countries, transformation of EU countries towards $\mathrm{CE}$ will be more dynamic. However, in order for it to happen, it is necessary (apart from the already-signalled issues) to take actions intended to increase $\mathrm{CE}$ awareness.

\section{Conclusions}

Given the current social and economic situation of the EU countries and the state of the natural environment, it seems there is no other option but to transition to CE. We are observing a global population growth and we are experiencing a barrier of a limited amount of raw materials throughout the world, hence the need to turn towards recycling and towards prevention of waste generation.
The European Union plays a key role in disseminating the CE concept. It has published a number of CE-related documents and it has obliged its member states to perform processes associated with transforming their economies towards CE.

The measurement and assessment of the undertaken activities in terms of putting CE into effect are fundamental issues for the proper implementation of CE. The monitoring should also apply to the progress of transformation towards CE [77] or to the efficiency of implementation of CE goals [34] at various levels (macro, meso and micro).

Reports, strategies and documents of international institutions as well as many scholarly publications feature an array of guidelines for constructing indicators for measuring $\mathrm{CE}$ at various levels. The European Commission too has created their own monitoring framework [34]. The proposed set of CE indicators is constantly being improved. The indicators created may be used further to conduct comparative analyses, e.g. between countries i.a. in terms of their progress in transitioning to $\mathrm{CE}$ [1], [98].

Given the above, the aim of this paper is to identify and group the EU-28 countries according to their advancement towards circular economy. Apart from an analysis of the literature, selected statistical analyses have been conducted. After a CE literature review, looking closely at the macro-level, the author decided to choose indicators which were selected by the European Commission for monitoring $\mathrm{CE}$ in the $\mathrm{EU}$.

The following results were obtained in the course of the research. The hierarchical cluster analysis showed that there are two groups of countries. The first group includes: Belgium, the Netherlands, Denmark, Luxembourg, Austria, Germany, Spain, France, Italy and the UK. The other countries are in the second cluster.

The same results were obtained when applying k-means clustering. The next analysis, the grade correspondence-cluster analysis, allowed identification of three groups of EU countries. The first one was made up of Germany, France, Spain, the United Kingdom, Italy, the Netherlands and Belgium, the second included Austria, Poland, Luxemburg, Finland, Sweden, Denmark, Greece, Slovenia and Portugal, while the third comprised Cyprus, Czechia, Malta, Lithuania, Latvia, Hungary, Ireland, Slovakia, Romania, Estonia, Croatia and Bulgaria. When comparing results obtained in these analyses, it may be concluded that the EU country most advanced in its transformation towards CE is Germany, while the least advanced countries include: Cyprus, Czechia, Malta, Lithuania, Latvia, Hungary, Ireland, Slovakia, Romania, Estonia, Croatia and Bulgaria, thus with the exception of Ireland-these are 
mainly the countries of the Central and Eastern Europe (after the political transformation) and the countries of the south of Europe.

Summing up the results, notice certainly needs to be given to the limitations of the analysis, of which the author is aware. They included the period for which the statistical data used in the analysis were available (2010-2018) and the lack of data for certain indicators that fall under the EC's monitoring frameworkwhich made it impossible to take them into account in the analysis. It also needs to be borne in mind that the measurement of the transformation towards $\mathrm{CE}$ at the macro-level is difficult and carries a risk of error. Moreover, the final result will always derive from assumptions that must be made for the analysis. The analysis performed in this paper may be further developed by, i.e. expanding the analysed time frame (according to available data), selecting other indicators, applying other statistical methods or constructing econometric models.

The analysis presented in the paper is a starting point for further research in the area of the subject-matter addressed in the article, i.a. conducting an in-depth analysis of actions for transforming a linear economy into a circular economy in the EU countries or investigating the impact of transformation of the economy towards $\mathrm{CE}$ on the economic growth and social and economic development in individual EU countries. A challenge in this regard would involve constructing a model of measurement of the progress of transformation towards $\mathrm{CE}$ and its impact on the social and economic development, which would take into account a cause-and-effect sequence of a change in the behaviour (and its dynamics in time) of all participants of the social and economic life (including producers, consumers, the public sector, academic and research institutions, non-governmental organizations, etc.) The author assumes that it will be the subject of interest of further research and analyses carried out by her.

Acknowledgements

Not applicable.

\section{Authors' contributions}

The author read and approved the final manuscript.

\section{Authors' information}

Ewa Mazur-Wierzbicka, Professor of the University of Szczecin. She specializes mainly in the field of corporate social responsibility (CSR), sustainable development and human resource management.

\section{Funding}

University of Szczecin.

Availability of data and materials

Not applicable.

\section{Declarations}

Ethics approval and consent to participate

Not applicable.

Consent for publication

Not applicable.

Competing interests

Not applicable.

Received: 25 May 2021 Accepted: 27 August 2021

Published online: 27 September 2021

\section{References}

1. Akerman E (2016) Development of circular economy core indicators for natural resources - analysis of existing sustainability indicators as a baseline for developing circular economy indicators. Master of Science Thesis; Royal Institute of Technology, Stockholm

2. Bastein ET, Roelofs E, Rietveld E, Hoogendoorn A (2013) Opportunities for a circular economy in the Netherlands. TNO, The Netherlands

3. Bechara L, Veiga E, Magrini A (2009) Eco-industrial park development in Rio de Janeiro, Brazil: a tool for sustainable development. J Clean Prod 17:653-661. https://doi.org/10.1016/j.jclepro.2008.11.009

4. BMUB, Division WR III 1 (ed.), German Resource Efficiency Programme II: Programme for the sustainable use and conservation of natural resources; Federal Ministry for the Environment, Nature Conservation, Building and Nuclear Safety, Berlin, Germany, 2016. https://www.bmu. de/fileadmin/Daten_BMU/Pools/Broschueren/german_resource_effic iency_programme_ii_bf.pdf Accessed 20 June 2020.

5. Bocken NMP, de Pauw I, Bakker C, van der Grinten B (2016) Product design and business model strategies for a circular economy. J Ind Prod Eng 33:308-320. https://doi.org/10.1080/21681015.2016.1172124

6. Boix M, Montastruc L, Pibouleau L, Azzaro-Pantel C, Domenech S (2012) Industrial water management by multiobjective optimization: from individual to collective solution through eco-industrial parks. J Clean Prod 22:85-97. https://doi.org/10.1016/j.jclepro.2011.09.011

7. Booth A, Sutton A, Papaioannou D (2012) Systematic approaches to a successful literature review. Sage, Los Angeles

8. Botezat EA, Dodescu AO, Vaduva S, Fotea SL (2018) An exploration of circular economy practices and performance among Romanian producers. Sustainability 10:3191. https://doi.org/10.3390/su10093191

9. Boulding KE (1966) The economics of the coming spaceship earth. In: Jarrett $H$ (ed) Environmental quality issues in a growing economy. Johns Hopkins University Press, Baltimore, pp 3-14

10. Cayzer S, Griths P, Beghetto V (2017) Design of indicators for measuring product performance in the circular economy. Int J Sustain Eng 10:289-298. https://doi.org/10.1080/19397038.2017.1333543

11. Circular Spain 2030. Spanish strategy for circular economy. https:// www.miteco.gob.es/es/calidad-y-evaluacion-ambiental/temas/econo mia-circular/espanacircular2030_def1_tcm30-509532.PDF Accessed 30 June 2020.

12. Club of Rome. The circular economy and benefits for society: jobs and climate clear winners in an economy based on renewable energy and resource efficiency. A study pertaining to Finland, France, the Netherlands, Spain and Sweden. Club of Rome 2015. https://clubofrome.org/ wp-content/uploads/2020/03/The-Circular-Economy-and-Benefits-forSociety.pdf Accessed 20 June 2020

13. Club of Rome. The circular economy and benefits for society: Jobs and climate clear winners in an economy based on renewable energy and resource efficiency. Club of Rome. 2016a. https://www.clubofrome. org/wpcontent/uploads/2016/03/The-Circular-Economy-and-BenefitsforSociety.pdf Accessed 20 June 2020.

14. Club of Rome. The circular economy and benefits: jobs and climate clear winners in an economy based on renewable energy and resource efficiency. A study pertaining to the Czech Republic and Poland. Club of Rome. 2016b. https://circulareconomy.europa.eu/platform/sites/ 
default/files/the-circular-economy-czech-republic-and-poland.pdf Accessed 20 June 2020

15. Commission of the European Communities. Communication from the Commission to the Council, the European Parliament, the European Economic and Social Committee and the Committee of the Regions. Thematic Strategy on the Sustainable Use of Natural Resources. COM(2005) 670 final; Commission of the European Communities: Belgium, Brussels, 2005. https://eur-lex.europa.eu/LexUriServ/LexUriServ. do?uri=COM:2005:0670:FIN:EN:PDF Accessed 24 June 2020

16. Commission of European Communities. Towards a Circular Economy: A Zero Waste Programme for Europe; Communication No. 398; (COM (2014), 398); Commission of European Communities: Brussels, Belgium, 2014. http://ec.europa.eu/environment/circular-economy/pdf/circulareconomy-communication.Pdf Accessed 16 June 2020

17. Commission of European Communities. Closing the Loop-An EU Action Plan for the Circular Economy; Communication No. 614; (COM (2015), 614); Commission of European Communities: Brussels, Belgium, 2015. https://eur-lex.europa.eu/resource.html?uri=cellar:8a8ef 5e8-99a0-11 e5-b3b7-01 aa75ed71a1.0012.02/DOC_18format=PDF Accessed 16 June 2020

18. Daly HE (1996) Beyond growth: the economics of sustainable development. Beacon Press, Boston

19. Declaración de Sevilla: el compromiso de las ciudades por la economía circular; Federación Española de Municipios y Provincias a.o., 2017. https://static1.squarespace.com/static/58a3606bb8a79bb8ae7d7847/t/ 58cbb35e3e00be7918d0adcd/ Accessed 25 Oct 2020

20. Deloitte Sustainability Consulting Central Europe. Gospodarka o obiegu zamkniętym. Jak wyzwolić potencjał z planowanych zmian; Deloitte Sustainability Consulting Central Europe: Warszawa, 2016

21. Dutch Ministry of Environment. A Circular Economy in the Netherlands by 2050. Dutch Ministry of Environment 2016. https://www.oecd.org/ environment/ministerial/whatsnew/2016-ENV-Ministerial-NetherlandsCirculareconomy-in-the-Netherlands-by-2050.pdf Accessed 14 Oct 2018

22. Eilering J, Vermeulen W (2004) Eco-industrial parks: toward industrial symbiosis and utility sharing in practice. Progr Ind Ecol Int J. 1:245-270. https://doi.org/10.1504/PIE.2004.004681

23. Elia V, Gnoni MG, Tornese F (2017) Measuring circular economy strategies through index methods: a critical analysis. J Clean Prod 142:27412751. https://doi.org/10.1016/j.jclepro.2016.10.196

24. Ellen MacArthur Foundation (EMF). Towards the Circular Economy 1: An Economic and Business Rationale for an Accelerated Transition. 2012. https://www.ellenmacarthurfoundation.org/assets/downloads/publi cations/Ellen-MacArthur-Foundation-Towards-the-Circular-Economyvol.1.pdf Accessed 30 June 2020

25. Ellen MacArthur Foundation (EMF). Towards the circular economy: opportunities for the consumer goods sector. 2013. https://www.ellen macarthurfoundation.org/assets/downloads/publications/TCE_Report2013.pdf Accessed 30 June 2020.

26. Ellen MacArthur Foundation (EMF). Delivering the Circular Economy: A Toolkit for Policymakers. 2015a. https://www.ellenmacarthurfounda tion.org/assets/downloads/publications/EllenMacArthurFoundation_ PolicymakerToolkit.pdf Accessed 30 June 2020

27. Ellen MacArthur Foundation (EMF). Circular Indicators: an approach to measuring circularity. Methodology. 2015b. Available online: https:// www.ellenmacarthurfoundation.org/assets/downloads/insight/Circu larity-Indicators_Project-Overview_May2015.pdf Accessed 30 June 2020

28. European Academies' Science Advisory Council (2016) Indicators for a circular economy. European Academies'Science Advisory Council Halle, Germany

29. European Commission. Europe 2020. A Strategy for Smart, Sustainable and Inclusive Growth. Communication from the Commission. Communication, Brussels 2010. http://ec.europa.eu/eu2020/pdf/COMPLET\% 20EN\%2OBARROSO\%20\%20\%20007\%20-\%20Europe\%202020\%20-\% 20EN\%20version.pdf Accessed 15 June 2020

30. European Commission. Roadmap to a Resource Efficient Europe COM(2011) 571 Final; European Commission: Belgium, Brussels, 2011. https://eur-lex.europa.eu/LexUriServ/LexUriServ.do?uri=COM:2011: 0571:FIN:PL:PDF Accessed 27 June 2020
31. European Commission. Measuring Progress Towards Circular Economy in the European Union-Key Indicators for a Monitoring Framework; European Commission: Strasbourg, France, 2018

32. European Commission. Annual Sustainable Growth Strategy 2020, COM(2019) 650 final, Communication from the Commission to the European Parliament, the Council, the European Central Bank, the European Economic And Social Committee, the Committee of the Regions and the European Investment Bank; European Commission: Belgium, Brussels, 2019. https://eur-lex.europa.eu/legal-content/EN/TXT/?uri= CELEX\%3A52019AE5232. Accessed 15 June 2020

33. European Commission. Communication from the Commission to the European Parliament, the Council, the European Economic and Social Committee and the Committee of the Regions, A New Circular Economy Action Plan. For a Cleaner and More Competitive Europe, COM(2020) 98 final; European Commission: Belgium, Brussels, 2020. https://eur-lex.europa.eu/legal-content/EN/TXT/?uri=CELEX\%3A520 20DC0098 Accessed 15 June 2020

34. European Economic and Social Committee. EESC Opinion: Monitoring Framework for the Circular Economy; European Economic and Social Committee, Belgium, Brussels, 2018

35. European Environmental Agency (EEA), Circular Economy in Europe. Developing the Knowledge Base. European Environmental Agency Report No 2/2016; Luxembourg: Publications Office of the European Union 2016. https://www.socialistsanddemocrats.eu/sites/default/files/ Circular\%20economy\%20in\%20Europe.pdf Accessed 28 June 2020

36. European Parliament; Council of the European Union. Directive 94/62/ EC on packaging and packaging waste; European Parliament and Council of the European Union: Brussels, Belgium, 1994. https://eur-lex. europa.eu/legal-content/PL/TXT/?uri=celex\%3A31994L0062 Accessed 30 June 2020

37. European Parliament; Council of the European Union. Directive 2000/53/EC on end-of life vehicles; European Parliament and Council of the European Union: Brussels, Belgium, 2000. https://eur-lex.europa.eu/ legal-content/EN/TXT/?uri=CELEX:32000L0053 Accessed 30 June 2020

38. European Parliament and of the Council. Decision No 1600/2002/EC laying down the Sixth Community Environment Action Programme, European Parliament and Council of the European Union: Brussels, Belgium, 2002. https://eur-lex.europa.eu/legal-content/EN/TXT/PDF/? uri=CELEX:32002D1600\&from=EN Accessed 30 June 2020

39. European Parliament; Council of the European Union. Directive 2002/96/EC on waste electrical and electronic equipment (WEEE); European Parliament and Council of the European Union: Brussels, Belgium, 2003. https://eur-lex.europa.eu/legal-content/PL/ALL/?uri= celex\%3A32002L0096 Accessed 30 June 2020.

40. Extremadura 2030: Strategy for green and circular economy. https://ec. europa.eu/growth/tools-databases/regional-innovation-monitor/polic ydocument/extremadura-2030-strategy-green-and-circular-economy-0 Accessed on 25 Oct 2020

41. Fan Y, Fang C (2020) Circular economy development in China-current situation, evaluation and policy implications. Environ Impact Assess Rev 84:106441. https://doi.org/10.1016/j.eiar.2020.106441

42. Federal public service Health, Food Chain Safety and Environment Belgium Federal Government. Ensemble faisons tourner l'économie en développant l'économie circulaire en Belgique. 21 mesures pour l'économie circulaire; Federal public service Health, Food Chain Safety and Environment Belgium Federal Government, 2016. https://www. health.belgium.be/en/node/30139 Accessed 25 Oct 2020

43. Fellner J, Lederer J, Schar C, Laner D (2015) Present potentials and limitations of a circular economy with respect to primary raw material demand. J Ind Ecol 21:494-496. https://doi.org/10.1111/jiec.12582

44. French Government, Ministry for the Ecological and Social Transition. First draft law "For a circular economy and better waste management"; French Government, Ministry for the Ecological and Social Transition, 2019. http://lamaisondeleconomiecirculaire.fr/wp-content/uploads/ ADI-fevrier-2019-PJL_\%C3\%A9conomie_circulaire.pdf Accessed 25 Oct 2020

45. Friant MC, Vermeulen WJV, Salomone R (2020) A typology of circular economy discourses: navigating the diverse visions of a contested 
paradigm. Resour Conserv Recycl 161:104917. https://doi.org/10.1016/j. resconrec.2020.104917

46. Garcia-Bernabeu A, Caballero AH, Pla-Santamaria D, Salas-Molina F (2020) A process oriented MCDM approach to construct a circular economy composite index. Sustainability 12:618. https://doi.org/10, 3390/su12020618

47. Geissdoerfer M, Savaget P, Bocken NMP, Hultink EJ (2017) The circular economy—A new sustainability paradigm? J Clean Prod 143:757-768. https://doi.org/10.1016/j.jclepro.2016.12.048

48. Geng Y, Fu J, Sarkis J, Xue B (2012) Towards a national circular economy indicator system in China: an evaluation and critical analysis. J Clean Prod 23:216-224. https://doi.org/10.1016/j.jclepro.2011.07.005

49. Georgescu-Roegen N (1971) The entropy law and the economic process. Harvard University Press, Cambridge

50. Ghisellini P, Cialani C, Ulgiati S (2016) A review on circular economy: the expected transition to a balanced interplay of environmental and economic systems. J Clean Prod 114:11-32. https://doi.org/10.1016/j. jclepro.2015.09.007

51. Ghisellini P, Ripa M, Ulgiati S (2018) Exploring environmental and economic costs and benefits of a circular economy approach to the construction and demolition sector. A literature review. J Clean Prod 178:618-643. https://doi.org/10.1016/j.jclepro.2017.11.207

52. Ghisellini P, Ulgiati S (2019) Circular economy transition in Italy. Achievements, perspectives and constraints. J Clean Prod 243:118360. https:// doi.org/10.1016/j.jclepro.2019.118360

53. Giannakitsidou O, Giannikos I, Chondrou A (2020) Ranking European countries on the basis of their environmental and circular economy performance: a DEA application in MSW. Waste Manag 109:181-191. https://doi.org/10.1016/j.wasman.2020.04.055

54. Graedel TE (1996) On the concept of industrial ecology. Annu Rev Energy Environ 21:69-98

55. Haas W, Krausmann F, Wiedenhofer D, Heinz M (2015) How circular is the global economy?: an assessment of material flows, waste production, and recycling in the European Union and the world in 2005. J Ind Ecol 19:765-777. https://doi.org/10.1111/jiec.12244

56. Hobson K, Lynch N (2016) Diversifying and de-growing the circular economy: radical social transformation in a resource-scarce world. Futures 82:15-25. https://doi.org/10.1016/j.futures.2016.05.012

57. Hossain MdU, Ng ST, Antwi-Afari P, Amor B (2020) Circular economy and the construction industry: existing trends, challenges and prospective framework for sustainable construction. Renew Sustain Energy Rev 130:109948. https://doi.org/10.1016/j.ser.2020.109948

58. Howard M, Hopkinson P, Miemczyk J (2019) The regenerative supply chain: a framework for developing circular economy indicators. Int J Prod Res 57:7300-7318. https://doi.org/10.1080/00207543.2018.15241 66

59. International green deal with France, Flanders and the United Kingdom; The Parliament Magazine, 2016. https://www.theparliamentmagazine. eu/printpdf/3931 Accessed 25 Oct 2020

60. Jia F, Yin S, Chen L, Chen X (2020) The circular economy in the textile and apparel industry: a systematic literature review. J Clean Prod 259:120728. https://doi.org/10.1016/j.jclepro.2020.120728

61. Johansson N, Henriksson M (2020) Circular economy running in circles? A discourse analysis of shifts in ideas of circularity in Swedish environmental policy. Sustain Prod Consum 23:148-156. https://doi.org/10. 1016/j.spc.2020.05.005

62. Kristensen HS, Mosgaard MA (2020) A review of micro level indicators for a circular economy - moving away from the three dimensions of sustainability? J Clean Prod 243:118531. https://doi.org/10.1016/j.jclep ro.2019.118531

63. Lakatos ES, Cioca L-I, Dan V, Ciomos AO, Crisan OA, Barsan G (2018) Studies and investigation about the attitude towards sustainable production, consumption and waste generation in line with circular economy in Romania. Sustainability 10:865. https://doi.org/10.3390/ su10030865

64. Lewandowski M (2016) Designing the business models for circular economy—-towards the conceptual framework. Sustainability 8:43. https://doi.org/10.3390/su8010043
65. Li WF, Zhang TZ (2005) Research on the circular economy evaluation index system in resource based city. Econ Manag J 8:82-86

66. Lieder M, Asif FMA, Rashid A, Mihelic A, Kotnik S (2017) Towards circular economy implementation in manufacturing systems using a multimethod simulation approach to link design and business strategy. Int J Adv Manuf Technol 93:1953-1970. https://doi.org/10.1007/ s00170-017-0610-9

67. Lifset R, Graedel TE. Industrial ecology: goals and definitions. In A Handbook of Industrial Ecology; Ayres RU, Ayres LW, Eds, Edward Elgar Publishing Limited: Cheltenham, UK, Northampton MA, USA, 2002; pp. 3-15, EISBN: 9781840645064

68. Liu JY (2012) Circular economy and environmental efficiency - the case of traditional Hakka Living System. Procedia-Soc Behav Sci 57:255-260. https://doi.org/10.1016/j.sbspro.2012.09.1183

69. Magnier, C.; Auzanneau, M.; Calatayud, P.; Gauche, M.; Ghewy, X.; Granger, M.; Margontier, S.; Pautard E. 10 Key Indicators for Monitoring the Circular Economy, The Monitoring and Statistics Directorate. France 2017. http://temis.documentation.developpement-durable.gouv.fr/ docs/Temis/0086/Temis-0086452/22978_2017_ENG.pdf Accessed 15 June 2020

70. Making Things Last: a circular economy strategy for Scotland; Scottish Government, 2016. https://www.gov.scot/publications/making-thingslast-circular-economy-strategy-scotland/ Accessed 20 Oct 2020

71. Marino A, Pariso P (2020) Comparing European countries' performances in the transition towards the circular economy. Sci Total Environ 729:138142. https://doi.org/10.1016/j.scitotenv.2020.138142

72. Marino C, Cencioni D, Eds. Circular Economy: benefits and good practices; Edizioni Ambiente: Milano, Italy, 2018; ISBN: 978-88-6627-230-4

73. Ministry for an Ecological and Solidary Transition, Ministry for the Economy and Finance. Roadmap for Circular economy - 50 measures for a 100\% circular economy; Ministry for an Ecological and Solidary Transition, Ministry for the Economy and Finance, 2018. https://www. ecologiquesolidaire.gouv.fr/leconomie-circulaire Accessed 25 Oct 2020

74. Ministry for the Environment, Land and Sea, Ministry of Economy. Towards a Model of Circular Economy for Italy_-Overview and Strategic Framework; Ministry for the Environment, Land and Sea, Ministry of Economy, 2018. https://circulareconomy.europa.eu/platform/sites/ default/iles/strategy_-_towards_a_model_eng_completo.pdf Accessed 25 Oct 2020

75. Ministry of Environment of Portugal. Leading the Transition: A Circular Economy Action Plan for Portugal: 2017-2020. Ministry of Environment of Portugal 2017. https://circulareconomy.europa.eu/platform/sites/ default/files/strategy_-_portuguese_action_plan_paec_en_version_3. pdf Accessed 16 June 2020

76. Momete DC (2020) A unified framework for assessing the readiness of European Union Economies to migrate to a circular modelling. Sci Total Environ 718:137375. https://doi.org/10.1016/j.scitotenv.2020.137375

77. Moraga G, Huysveld S, Mathieux F, Blengini GA, Alaerts L, Van Acker K, Dewulf J (2019) Circular economy indicators: what do they measure? Resour Conserv Recycl 146:452-461. https://doi.org/10.1016/j.resco nrec.2019.03.045

78. Murray A, Skene K, Haynes K (2017) The circular economy: an interdisciplinary exploration of the concept and application in a global context. Bus Ethics 140:369-380. https://doi.org/10.1007/s10551-015-2693-2

79. Niero M, Hauschild MZ, Hoffmeyer SB, Olsen SI (2017) Combining ecoefficiency and eco-effectiveness for continuous loop beverage packaging systems: lessons from the Carlsberg circular community. J Ind Ecol 21:742-753. https://doi.org/10.1111/jiec.12554

80. OECD. Green Growth Indicators 2017; OECD, 2017

81. Parchomenko A, Nelen D, Gillabel J, Rechberger H (2018) Measuring the circular economy - a multiple correspondence analysis of 63 metrics. J Clean Prod 210:200-216. https://doi.org/10.1016/j.jclepro.2018.10.357

82. Pearce, D.; Turner, R. Economics of Natural Resources and the Environment; Johns Hopkins University Press: Baltimore, USA, 1990; ISBN-13: 978-0801839870

83. Pieroni MPP, MCAloone TC, Pigosso DCA (2020) From theory to practice: systematising and testing business model archetypes for circular economy. Resour Conserv Recycl 162:105029. https://doi.org/10.1016/j. resconrec.2020.105029

84. Plastic News Europe. New German packaging law to hit market in 2019 https://www.plasticsnewseurope.com/article/20180703/PNE/18070 
9983/new-german-packaging-lawto-hit-market-in-2019 Accessed 20 June 2020

85. Pomberger R, Sarc R, Lorber KE (2017) Dynamic visualisation of municipal waste management performance in the EU using Ternary Diagram method. Waste Manage 61:558-571. https://doi.org/10.1016/j.wasman. 2017.01.018

86. Potting J, Hanemaaijer A (2018) Circular economy: what we want to know and can measure. Framework and baseline assessment for monitoring the progress of the circular economy in the Netherlands. PBL Netherlands Environmental Assessment Agency, The Hague

87. Potting J, Hekkert M, Worrell E, Hanemaaijer A (2016) Circular economy: measuring innovation in product chains. PBL Netherlands Environmental Assessment Agency, The Hague

88. Saavedra YMB, Iritani DR, Pavan ALR, Ometto AR (2018) Theoretical contribution of industrial ecology to circular economy. J Clean Prod 170:1514-1522. https://doi.org/10.1016/j.jclepro.2017.09.260

89. Sehnem S, Vazquez-Brust D, Pereira SCF, Campos LMS (2019) Circular economy: benefits, impacts and overlapping. Supply Chain Manag 24:784-804. https://doi.org/10.1108/SCM-06-2018-0213

90. Singh J, Ordonez I (2016) Resource recovery from post-consumer waste: important lessons for the upcoming circular economy. J Clean Prod 134:342-353. https://doi.org/10.1016/j.jclepro.2015.12.020

91. Stahel WR. The Performance Economy; Palgrave Macmillan: UK, 2010; ISBN-13: 978-0230584662

92. The Council of the European Communities. Council Directive 75/442/ EEC on Waste; The Council of the European Communities: Brussels, Belgium, 1975. https://eur-lex.europa.eu/legal-content/EN/ALL/?uri= CELEX\%3A31975L0442 Accessed 10 Oct 2020

93. The Council of the European Communities. Council Regulation (EEC) No 259/93 on the supervision and control of shipments of waste within, into and out of the European Community; The Council of the European Communities: Brussels, Belgium, 1993. https://eur-lex.europa. eu/legal-content/EN/ALL/?uri=celex:31993R0259 Accessed 10 Oct 2020

94. The Council of the European Communities. Council, Directive 85/337/ $\mathrm{EEC}$ on the assessment of the effects of certain public and private projects on the environment; The Council of the European Communities: Brussels, Belgium, 1985. https://eur-lex.europa.eu/legal-content/ EN/TXT/?uri=CELEX\%3A31985L0337 Accessed 10 Oct 2020

95. The Council of the European Union. Council Directive 1999/31/EC on the landfill of waste; The Council of the European Union: Brussels,
Belgium, 1999. https://eur-lex.europa.eu/legal-content/EN/TXT/?uri= CELEX\%3A31999L0031 Accessed 10 Oct 2020

96. The EREK core team \& VDI Centre for Resource Efficiency; EREK, 2019. https://www.resourceeicient.eu/en/erek-core-team \& https://www. resourceeicient.eu/en/intermediary/vdi-centre-resource-eiciency-vdizre Accessed 20 Oct 2020

97. The French Ministry of Ecological and Solidarity Transition. France Unveils Circular Economy Roadmap. The French Ministry of Ecological and Solidarity Transition. 2018. https://www.ecologique-solidaire.gouv. $\mathrm{fr} /$ sites/default/files/FREC\%20-\%20EN.pdf Accessed 28 June 2020

98. Walker S, Coleman N, Hodgson P, Collins N, Brimacombe L (2018) Evaluating the environmental dimension of material efficiency strategies relating to the circular economy. Sustainability. https://doi.org/10.3390/ su10030666

99. WBCSD. CEO Guide to the Circular Economy. 2017. www.wbcsd.org/ Clusters/CircularEconomy/Resources/CEO-Guide-to-the-Circular-Econo my Accessed 10 Jan 2019

100. Wisse E (2016) Assessment of indicators for circular economy: the case for the Metropole Region of Amsterdam. Faculty of Geosciences Theses; Utrecht University, Utrecht

101. World Bank (2017) The little green data book 2017. World development indicators. World Bank, Washington

102. Xuan L, Baotong D, Hua Y (2011) The research based on the 3-R principle of Agro-Circular Economy Model The Erhai Lake Basin as an example. Energy Procedia 5:1399-1404. https://doi.org/10.1016/j. egypro.2011.03.242

103. Yuan Z, Bi J, Moriguichi Y (2006) The circular economy: a new development strategy in China. J Ind Ecol 10:4-8. https://doi.org/10.1162/10881 9806775545321

104. Zeliaś, A. Taksonomiczna analiza przestrzennego zróżnicowania poziomu życia w Polsce w ujęciu dynamicznym, Wydawnictwo Akademii Ekonomicznej w Krakowie: Kraków, 2000; ISBN: 83-7252-065-8

105. Zeng H, Chen X, Xiao X, Zhou Z (2017) Institutional pressures, sustainable supply chain management, and circular economy capability: empirical evidence from Chinese eco-industrial park firms. J Clean Prod 155:54-65. https://doi.org/10.1016/j.jclepro.2016.10.093

\section{Publisher's Note}

Springer Nature remains neutral with regard to jurisdictional claims in published maps and institutional affiliations.

\section{Submit your manuscript to a SpringerOpen ${ }^{\circ}$ journal and benefit from:}

- Convenient online submission

- Rigorous peer review

- Open access: articles freely available online

- High visibility within the field

- Retaining the copyright to your article

Submit your next manuscript at $\boldsymbol{\nabla}$ springeropen.com 